\title{
1
}

\section{Democratic theories and potential for influence for civil society in spatial planning processes}

\author{
Lillin Knudtzon
}

\section{Introduction}

As the landscape convention bides countries to plan democratically, there is a need to decipher what democracy can imply. This chapter focuses on the place of civil society in four contemporary theoretical approaches to democracy, discussing the consequences of each for processes of land-use decisions.

Planning and design processes involve a spectrum of actors, with designers, (landscape) architects, real-estate developers, public planners and politicians being core part-takers. They may agree in principle that a process should have democratic legitimacy, but may have diametrically different ideas of what that implies in practice. Elaborating on ideals for democracy may clarify the theoretical terrain and facilitate communication in a policy area with immanent contestations.

What does democracy imply? Following the Greek words demos (people) and kratos (ruling), this text centres around inclusion of civil society in planning processes: who are 'the people', and what does their 'ruling' imply within each approach to democracy? I describe what potential each holds for inclusion of civil society at different stages of a planning process, distinguishing between liberal, participatory, deliberative and radical understandings of democracy. As the liberal (with its core role of the people voting) is dominant in many Western societies today, I demonstrate that the others represent alternative perspectives pointing to richer processes but in alternative ways at different stages. The participatory gives prevalence to local and direct power, preferably in initiating phases. The deliberative seeks construction of a best possible knowledge base through discursive representation as well as well-reasoned solutions. The radical challenges the hegemonic power and seeks mobilization of marginalized voices.

The chapter starts with a short background on challenges for public participation followed by a review of the four approaches to democracy. The next section 
presents a model of ten generic stages of a planning process, and discusses concrete and practical consequences on public inclusion depending on conceptions of democracy. The chapter concludes by highlighting implications of democratic models for public planners seeking stronger democratic legitimacy.

\section{Challenges of participation as democratic inclusion}

Over recent decades, the ambition of public participation has become a popular answer to a challenge of more democratic inclusion, and has made its way into appropriate legislation. This is also the case in the European Landscape Convention, as article $5 \mathrm{c}$ bids each party:

... to establish procedures for the participation of the general public, local and regional authorities, and other parties with an interest in the definition and implementation of the landscape policies ... (CoE 2000, p. 4)

The associated Guidelines provide further ambitions and recommendations for public inclusion (Jones and Stenseke 2011). Still, including phrases in legislation does not necessarily have large impacts in practice. Numerous texts problematize inclusiveness of actual planning processes related to different dimensions. Classical lines of exclusion are gender, social class, age, race and ethnicity. These are well recognized in democratic theory and may be labelled external as they concern how people are kept outside political processes (Young 2000 , pp. 52-55). Exclusions can also be more subtle or internal as 'they concern ways that people lack effective opportunity to influence the thinking of others even when they have access to fora and procedures of decision-making' (ibid., p. 55). Another version of this is cognitive closure, as described by Hanssen and Saglie (2010), where the dominant discourses in planning exclude certain arguments, perspectives or understandings.

In the planning arena, differences in power might follow difference in economic interests. Actors with economic interests in developments might oppose interference from civil society as it may imply a risk of prolonged decision-making processes and diminishing profit. Unintended shortcomings of participatory ambitions in planning are aptly summed up by Jean Hillier (2003, p. 157):

The commitment to increase participation in planning practice has tended to overlook populist mobilization of public opinion, often favouring networks of articulate, middle-class property owners to the exclusion of the voices of the marginalized and of planning officers. In such instances, public involvement is 'skewed' and 'public opinion' distorted.

Still, while acknowledging possible pitfalls of public participation, theoreticians and researchers keep promoting democratic inclusion in planning (Forester 2009; Hillier 2002; Jones and Stenseke 2011; Sager 2013). I will join forces with them, pointing to different potentials for influence for civil society depending on understandings of democracy. 


\section{A brief review of democratic theories and their respective accounts of civil society}

Democracy can be categorized as a contested concept (Cunningham 2002). There are numerous ways to label and group models of democracy. Mine largely follows common categorizations (Held 2006; Purcell 2008) but is adapted by placing civil society ${ }^{1}$ as a distinguishing feature.

To highlight main differences for civil society in decision-making in planning, I start by presenting the distinct divide between a liberal and a republican tradition (Habermas 1996; Held 2006). Within a liberal understanding, primacy is given to the individuals' rights and freedom from the state, whereas in the republican tradition exchange of arguments and active citizenship are core values. In the liberal understanding, individuals are the only relevant entities, whilst the republican is oriented towards collectives and communities, with Rousseau advocating the ideal of identifying a 'general will' ${ }^{2}$ that all citizens should be bound by.

The republican tradition has branched in several directions, where participatory democracy and deliberative democracy have especially influenced planning theory over recent decades. As there are different versions of these, and as communicative and collaborative planning theory often merge aspects from both, core elements for the reasoning in this text will be specified. In addition to these, a radical perspective on democracy is included. Some radical approaches to democracy have seen civil society as part of the state and as reproducing a repressive structure (Scott and Marshall 2009, p. 83). Later approaches, such as Chantal Mouffe's, see participation of citizens as essential. Her version explicitly 'shares the preoccupation of various writers who want to redeem the tradition of civic republicanism' (Mouffe 2005b, p. 19). All three versions, opposing the liberal approach, may be labelled radical due to their quest for an expansion of arenas for democratic processes and their challenge of the established liberal construct and its thin democracy (Vick 2015, p. 206). However, the term 'radical democracy' is in this text reserved for an approach that goes further in advocating the need for disclosure of differences of interests.

Hence, I put forward four ideal typical ${ }^{3}$ versions of democracy - liberal, participatory, deliberative and radical - and stress the place of civil society within them. For each I focus on core values, citizens' role in a democratic process, view on legitimacy of decisions and the natural place of public participation in planning.

\section{Liberal democracy: indirect power through voting}

The term 'liberal' appears in contrasting ways within literature and everyday language. Here it is not used in the common (North American) understanding as being politically progressive and inclusive, but, rather, connected to classical liberal political theory founded on liberalism (Held 2006, p. 59). This approach to democracy is also called 'aggregative', due to its basic view of a right decision as the aggregation of individual votes. 
Schumpeter's (1942) assessment of democracy as a method for making decisions remains a core within a liberal understanding of democracy. The primary roles of the 'demos', or citizens, are as voters in elections and as rights holders, whereas elected representatives make the calls between elections. Decisions made by representative bodies are a priori legitimate as long as no basic individual rights to freedom and property are violated. Citizens' option to not vote for politicians in further elections, should they disagree with decisions, is a crucial element giving citizens some power.

Applying this democratic theory to a planning context implies that public participation should consist of enabling legitimate stakeholders in general and neighbouring property holders in particular to secure their (primarily economic) interests, as their interference and defence of their properties' value is considered legitimate. Written inputs to hearings, as well as protesting, lobbying and activism from civil society are all actions in line with this understanding of democracy, as a right to protecting your own interests is a main characteristic. Politicians have an incentive to listen to (powerful) citizens to secure re-election.

Although this understanding of democracy is rarely advocated as an ideal in planning theory, some advocate the market as a better indicator of civic opinion in planning than participatory efforts (Pennington 2002). Furthermore, a minimalist approach may in practice be a customary solution in actual processes, as it can be seen as time efficient and possibly requiring less effort from planners. Property developers seeking to minimize interference will often hold this view of democracy.

\section{Participatory democracy: local and direct power}

Participatory democracy implies that people have genuine influence in decision-making (Pateman 1970), and advocates a transformation to further the principles of direct democratic decision-making (Vick 2015). Decisions need to be grounded in broad public participatory processes where those affected are consulted and preferably given decisive power, ideally resulting in an outcome based on locally based consensus. This builds on a deeply different view of the citizen compared with the one represented by liberal democracy. Citizens are seen as resources to develop well-founded and viable solutions that are acceptable to those who are affected.

Participation by all who are affected is a practical problem when the number of people rises (the problem of scale). Hence, a participatory approach may work best on small-scale polities. Detailed planning may be at a scale where a participatory approach is closing in on being practically feasible. Face-to-face involvement in meetings and workshops, and development of locally adjusted solutions after broad recruitment to reach all affected, are participatory approaches matching this view. Several planners have advocated these ways of practical working (Forester 2009; Innes and Booher 1999).

Participatory democracy implies a strong position for civil society, and addresses imbalances of power, particularly focusing on the exclusion of women (Pateman 1989). However, it risks not addressing these issues properly in prac- 
tice, thereby assuming communities as one-dimensional. The outcomes may be challenged by others in a pluralistic society, and might therefore still imply protests or activism, hence breaking with the idea of consensus-based solutions found in participatory democracy.

As participatory democracy shifts the decisive power from elected politicians to locally based process participants, it risks becoming elitist, as citizens' strength of voice will vary. A strong preference for the local scale may also lead to disregard of matters of national or global importance, such as some environmental impacts (Strand and Næss 2017).

\section{Deliberative democracy: power through argumentation}

Within deliberative democracy, citizens are seen as political beings oriented towards the best outcome and as producers of arguments. Decisions are only legitimate when well-reasoned (Gutmann and Thompson 2004). Reasons should be acceptable to free and equal persons seeking fair terms of co-operation (ibid., p. 3). The processes should be inclusive (Dryzek and Niemeyer 2010) so everyone may be allowed to challenge them. Habermas' (1996) theory of communicative action and his defence of the republican tradition have been influential. Democracy becomes a way to explore and find good solutions for the society at large, and the civil society is of paramount importance to achieve this. The legitimacy of the outcome is dependent on the justification to those affected.

Within this framework, the purpose of exchanges of arguments is to get all (or most) important aspects of an issue scrutinized and included in a decision process where new insight and preference formation is achieved through dialogue. To counter the problem of scale, this can be done through representation of discourses ${ }^{4}$ rather than people: discursive representation.

Communicative planning theorists draw on Habermas and emphasize the formation of meaning through dialogue. However, they explicitly do not embrace a notion of power-free consensus (for example, Forester 2009; Healey 1993; Sager 2013).

For planning, deliberative democracy implies that civil society, both people and organizations, are actively mobilized to ensure all relevant discourses are represented and that potential new insights and perspectives surface. As this position acknowledges pluralism, claims should be considered and answered in land-use decisions, but not necessarily met.

Although the main way of influencing is through argumentation, activism can also be an important supplement of action (Young 2001, p. 678).

\section{Radical democracy: transformative power}

Finally, there are the radical perspectives voiced by theoreticians such as Jacques Rancière and Chantal Mouffe. Based on a diagnosis of hegemonic status for neo-liberal values, profound power imbalances and irreconcilable differences in today's Western societies, Mouffe warns against concealment of power and real 
interests through consensus-oriented processes. She stresses that the political aspect of decisions implies deep and irreconcilable contestations, meaning that consensus represents concealment of power structures (Mouffe 2005a).

Detailed planning will often have the potential to become political in this sense (Hillier 2002). Radical planning should, then, confront power through agonistic ${ }^{5}$ processes where profound differences of interests are recognized and respected (Pløger 2004). The social constructedness of knowledge is important and implies a temporality and plurality of knowledge (Rydin 2007). Civil society's role is to expose pluralism and differences in interests. The approach is positive to direct action as a way to express both passion and standpoint. Coalitions of marginalized and disadvantaged groups should work with strategies to counter current hegemonic power relations (Purcell 2009, p. 159). As Mouffe says, '[a] healthy democratic process calls for a vibrant clash of political positions and an open conflict of interests' (Mouffe 2005b, p. 6), intended to lead to 'a profound transformation of the existing power relations and the establishment of a new hegemony. This is why it can properly be called "radical"' (Mouffe 2005a, p. 52).

\section{A generic planning model and democratic openings for civil society}

Although sharing important similarities across nations, physical planning does have distinct national features depending on factors such as political tradition and property regimes. Furthermore, features of the land considered for development are influential, implying that planning a public park will require different actions from everyone involved than deciding on the use of a privately owned lot in the outskirts of an industrial park. Is it desirable, possible or meaningful to draw up a generic model of local (detailed) planning? I propose that the answer is yes, as it makes it possible to concretize and compare the otherwise abstract issues.

I propose that a planning process can be divided into ten stages, as seen in Table 1.1, where the main actors and their roles are indicated. The model is loosely based on the Norwegian system, but includes more stages. Planning systems in different countries might have many or few of these stages. The model comprises public planning monopoly and private right of initiating development. Applicability of stages may vary if the land is privately or publicly owned.

In the following paragraphs, I will discuss the potential influence of civil society under each stage and relate it to the approaches to democracy, abbreviated in Table 1.1 as L (liberal), P (participatory), D (deliberative) and R (radical).

Stage 0 is included to stress that new initiatives relate to higher tier plans and infrastructure frameworks. This normally involves compliance with, fulfilment of or adjustment to the overarching expectations, or to apply for exemption from them. Compliance normally guarantees democratic legitimacy for the process. However, from a perspective of seeing the local as the paramount level for decision-making (as the participatory and radical approach might do), overarching plans and instructions may be seen as unwelcome restrictions. 
Table 1.1 Planning stages, main actors and potential for civil society influence depending on democratic approach

\begin{tabular}{|c|c|c|c|c|c|}
\hline Planning stages & Main actors & $\mathrm{L}$ & $\mathrm{P}$ & $\mathrm{D}$ & $\mathrm{R}$ \\
\hline \multicolumn{6}{|c|}{ 0. Master plans and requirements impose limitations and directions } \\
\hline $\begin{array}{l}\text { 1. Initiative - forming of } \\
\text { ideas }\end{array}$ & $\begin{array}{l}\text { Initiative by either Public Planning Office (PPO) or } \\
\text { Property Developer (PD) }\end{array}$ & - & $x$ & O & $x$ \\
\hline $\begin{array}{l}\text { 2. Discussions of broad } \\
\text { set of frames }\end{array}$ & Public planning officers and initiators (PPO or PD) & - & $x$ & O & - \\
\hline $\begin{array}{l}\text { 3. Initiative made public / } \\
\text { invitation to civil society } \\
\text { to take part }\end{array}$ & Initiators (PPO or PD) and/or Public Planning Office & - & O & O & $\mathrm{O}$ \\
\hline $\begin{array}{l}\text { 4A. Response or input by } \\
\text { civil society }\end{array}$ & $\begin{array}{l}\text { State / national / regional / local level public bodies } \\
\text { Civil organizations with diverse mandates / local } \\
\text { community / neighbours }\end{array}$ & $x$ & - & $x$ & $x$ \\
\hline $\begin{array}{l}\text { 4B. Collaboration and } \\
\text { drafting of } \\
\text { plan/agreement }\end{array}$ & $\begin{array}{l}\text { Initiators (PPO or PD) with consultants / architects } \\
\text { State / national / regional / local level public bodies } \\
\text { Civil organizations with diverse mandates / local } \\
\text { community / neighbours } \\
\text { Public planning office } \\
\text { Politicians }\end{array}$ & - & $x$ & O & - \\
\hline $\begin{array}{l}\text { 5. Drawing up full } \\
\text { proposal }\end{array}$ & Initiators with consultants/architects & - & O & - & - \\
\hline $\begin{array}{l}\text { 6. Municipal handling } \\
\text { and alterations }\end{array}$ & $\begin{array}{l}\text { Public Planning Office } \\
\text { Initiators (PPO or PD) with consultants/architects }\end{array}$ & - & O & - & - \\
\hline $\begin{array}{l}\text { 7. Political consideration - } \\
\text { leading to approval for } \\
\text { hearing or rejection/ } \\
\text { amendments }\end{array}$ & Elected representatives/politicians & $\mathrm{O}$ & - & - & $\mathrm{O}$ \\
\hline $\begin{array}{l}\text { 8. Hearing of proposed } \\
\text { plan - response by } \\
\text { stakeholders }\end{array}$ & $\begin{array}{l}\text { State / national / regional / local level public bodies } \\
\text { Civil organizations with diverse mandates / local } \\
\text { community / neighbours }\end{array}$ & $x$ & - & $x$ & $\mathrm{O}$ \\
\hline $\begin{array}{l}\text { 9. Political consideration } \\
\text { and decision }\end{array}$ & $\begin{array}{l}\text { Elected representatives/politicians (Others through } \\
\text { lobbying/interference) }\end{array}$ & $\mathrm{O}$ & - & $\mathrm{O}$ & $x$ \\
\hline 10. Approval or appeal & $\begin{array}{l}\text { Higher level government (approval) } \\
\text { Higher level government (appeal) } \\
\text { Initiators (if proposition is denied) } \\
\text { Civil society / neighbours (appeal) }\end{array}$ & - & - & - & $\mathrm{O}$ \\
\hline
\end{tabular}

Note: a. 'Property Developer' comprises private companies, publicly owned companies and local communities.

Key: $\mathrm{L}=$ Liberal; $\mathrm{P}=$ Participatory; $\mathrm{D}=$ Deliberative; $\mathrm{R}=$ Radical; $\mathrm{O}=$ Possible stage for civil society engagement; $X=$ Central stage for civil society engagement.

Stage 1 is making the initiative, having an idea and formally opening a planning case. Public planners have traditionally done this, but in some countries, private developers as well as local communities may put forward planning applications. Consultancy firms and/or architects can be involved as technical expertise. Civil 
society is not traditionally part of this phase. Plans initiated in a local community by the people who will use the area can be truly participatory and radical in a democratic sense. However, neighbourhood plan initiatives may also originate from a desire to exclude groups.

Stage 2 is where the initiative is adapted to frames set by strategic plans and formal requirements. If the initiators are external, they meet the appropriate public planning authority and negotiate. Representatives for other public agencies may set further specifications or constraints. Civil society is often excluded from this phase, in line with a liberal approach. Particularly the participatory approach, but also the deliberative, would endorse wider inclusions at this stage. Radical democracy, however, voices scepticism of co-optation and of negotiations that may close a process prematurely. Stage 2 may to a large degree be defining for the project, as main lines are drawn and fundamental decisions are made, limiting the possible input from the upcoming stages (Nordahl 2006).

Stage 3 is the announcement of the initiative. It may set off genuine public participation and deliberation. However, mandatory requirements are often limited to public information and/or letters to legal neighbours. Institutionalized consultation parties (for example, government agencies, NGOs and formal interest groups) might also be informed. Within a participatory framework for planning, those affected should actively be invited in. Active inclusion is in line with a deliberative and radical understanding of democracy also, but the liberal approach is content with information only.

Stage 4 is here given two different versions: A or B dependent on the nature of the initiated engagement. At this point, the proposed development is not yet fully designed. Stage 4 might take the form of exchanges of viewpoints, either in writing or in meetings (4A), or it can be in a format where the public influences directly, gives ideas and draws up alternatives in (for example) workshops, thus closing in on a participatory approach (4B).

4A may hold deliberative qualities, where arguments are generated and then met with acceptance or with counterarguments. However, a more normal progress is stakeholders submitting their concerns in writing without any dialogical process. Public authorities (at state, regional or local level) are routine partakers who normally feed in assessments and requirements at this time. Neighbours, local organizations and different interest organizations might also provide perspectives and issues of concern.

Scarce information about a proposed plan might yield few responses or reactions. A result may be that unaddressed contested issues could erupt later in the process.

Within a liberal approach, where civil society's role is to pursue individual interests, sending notifications directly to neighbours and other legal stakeholders will suffice. This implies a risk of a lack of spokespeople for interests that are not private and individual. Within a deliberative approach, there is an ambition to have special focus on such interests through discursive representation. Mobilizing counter hegemonic voices at this stage is paramount for a radical approach.

$4 \mathrm{~B}$ represents an ambition of engaging civil society directly in forming the 
proposal and seeking consensus on the outcome. In a successful version of this, with initiators, planners, public agencies, technical expertise, politicians and a comprehensive selection from civil society collaborating in finding solutions, stages 5 and 6 become incorporated. Stage 7 is the logical end-stage where final approval is granted.

A radical approach to democracy opposes the striving towards consensus, as it is seen as likely to support hegemonic positions and legitimize the existing relations of power instead of challenging it (Mouffe 2000; Purcell 2008). The liberal approach opposes the shift of power away from elected politicians implied by 4B.

In stage 5 (following 4A), the proposal is concretized and designed by technical expertise (consultants/architects working with/for the initiator). If the initiator is a private developer or the community, this might be done in dialogue with public planning officers who can advise on regulations and requirements (integrating stage 6).

Depending on legislation, the proposal might be obliged to present input from stage $4 \mathrm{~A}$ and comment on how these are considered and potentially incorporated into the plan. This might embody deliberation where addressed issues are discussed and countered with arguments.

Within a deliberative approach to democracy, all relevant discourses should be addressed and incorporated as a part of the legitimation of the basis for decision. This is not crucial in the liberal approach, as it does not require a link between arguments and decisions.

Stage 6 is the processing of the plan through the professional system in the municipality, ultimately resulting in a concrete plan proposal to the politicians. The main actors are the public planning officer (PPO) and initiators moulding the proposal to existing requirements, politicians' expectations and realistic scenarios of development. The openness of this process has implications for the public's awareness of the emerging proposal and interests connected to it.

Stage 7 consists of local political consideration and temporary endorsement of the plan to put it forward for comments in a hearing. Approaching politicians in connection to this stage - lobbying to make sure they are aware of interests and standpoints - may be an efficient channel of influence for developers. It may also be used by civil society if the public is amply aware of the content of the upcoming proposal. Lobbying is normally to impose already established positions, not to undertake explorative deliberation. Hence, use of this channel of influence is mostly in line with liberal and radical democracy.

Stage 8 is the official hearing of a fully drawn proposal. It can take the form of a classical liberal democratic hearing where stakeholders are informed and invited to state their views. As the physical dimensions and consequences of the proposal are now easier to grasp, this is the stage where civil society often becomes aware and aroused for the first time. At this point any adversarial nature of the process may become apparent. Actors may position themselves as adversaries with different positions in a struggle. The issues will then (if not already) become political in Mouffe's sense, with clear lines of disagreement.

A deliberative dimension may be present if this is civil society's first 
opportunity to influence through argumentation or if the land use is not very contested. Information and arguments are supplied to further new insight and deeper understanding. A deliberative approach seeks to resolve disagreements by revealing the strengths and weaknesses of arguments. Within a radical framework, the issues should be debated in agonistic confrontations where consensus is not the goal. However, compromises can be acceptable within this framework (Mouffe 2000, p. 102).

A radical democracy implies that the planning process will gain legitimacy if differences are transparent and diverging options or opportunities for the coming physical results are made visible. This is in line with a liberal democratic approach where different conflicts of interest are acknowledged and expected to be handled through a majority decision by elected politicians.

Stage 9 is the final local political consideration. Civil society actors may use tools such as protests, petitions, media and lobbying to influence politicians. Lobbying conforms with a liberal tradition, but it is not inherent in either participatory or deliberative democracy. In radical democracy, however, any way to voice your view is appropriate as the approach specifically welcomes passion and mobilization of marginal voices.

Stage 10 follows decision-making. If the plan proposal is rejected, the initiator may in some planning systems appeal the decision, or adjust their proposal to try again (returning to stage 5). There may also be additional levels of state or national approval. Furthermore, some countries may grant a right of appeal to different actors, such as civil society or public bodies, if they disagree with the approval. However, at some point, a final decision to proceed or not must be made, although the radical perspective promotes temporality on solutions.

\section{Conclusion}

To be legitimate, land-use decisions need to be democratically grounded. Through the review above of the consequences of democratic ideals on the stages in planning processes, I have discussed how diversely democratic legitimacy may be understood in practice. Different actors in a land-use decision process may have opposing anticipations. The distinction between ideal typical versions of democracy enables analysis, discussion and evaluation of the legitimacy of a concrete planning process across frames of reference. It also highlights alternative positions for public planners to explore, when deciding on appropriate actions for a specific planning process. Suitable actions may depend on context, such as institutional frames, civic culture, type of development, and level of existing and potential conflicts.

Two especially potent factors are the ownership of the land in question (public or private) and the importance of the planned landscape for the public. Private ownership may limit potential civic involvement formally depending on a country's legislation, but it may also restrain participation through more subtle mechanisms if private developers are in charge of designing the process. As for the importance of the landscape for the general public, resources may be well 
spent on securing wider involvement and embracing politically heated engagement if the area in question is of high public value.

I have argued that the liberal democratic type is a minimal approach to civil society involvement. For the public planner it implies making information available, sorting input, and leaving the weighing and considerations to elected representatives, granting citizens mainly indirect power. A public planner may seek to supplement this by drawing on the approaches from the republican tradition of active citizenship and 'the people' seen as a resource.

The participatory approach implies identifying and actively mobilizing those affected by a proposed change to seek agreed solutions. It requires skills in facilitating consensus and compromise in organic and creative processes. Such processes could gain high local legitimacy, but are time-consuming and might be unrealistic in a world of diverse and polarized interests. When implying genuine redistribution of power to a (non-elected) local level, it may challenge established political structures.

The deliberative approach seeks a foundation for judgement and preference formation in informed and inclusive dialogues. The inclusiveness and the quality of the argumentation and considerations are the most important aspects for legitimacy. Hence, the public planner must secure transparency of considerations and make sure actors who can bring discourses to the table are included. The approach does not challenge the decisive power of elected politicians.

Within radical democracy the role of the planner is to ensure transparency to enable civil society to mobilize diverse interests and influence through direct action and lobbying. Redistribution of power and challenging the hegemonic structures is inherent.

In a society with increasingly different publics, with pluralistic and contradictory interests, and the traditional class lines of power and interests being blurred and multifaceted, the liberal approach to a democratic planning process becomes too thin. Hence, there is a need to supplement and incorporate approaches from the participatory, deliberative and radical understandings of democracy. Embracing any other approach to democracy than the liberal implies that the planner no longer only expedites the technical and administrative process and acts as bureaucrat for the politicians, but is also a facilitator for a deeper and fuller democratic process.

\section{Notes}

1. Civil society refers to public life as contrasted with the family and the state, comprising public participation in voluntary associations, mass media, and as voiced citizens (Scott and Marshall 2009, p. 83).

2. The 'general will' should be distinguished from the 'will of all', as the first is a judgement about the common good and the second 'a mere aggregate of personal fancies and individual desires' (Held 2006, p. 46).

3. 'Ideal typical' implies that they are constructs made to communicate the essence of each type.

4. A discourse may be defined as 'a shared way of comprehending the world embedded in language' (Dryzek and Niemeyer 2010, p. 31)

5. The distinction between agonism, understood as struggle between adversaries, and antagonism, understood as struggle between enemies, is crucial (Mouffe 2000, pp. 102-103). 


\section{References}

CoE (Council of Europe) (2000). The European Landscape Convention, Florence: European Treaty series No 176.

Cunningham, F. (2002). Theories of Democracy: A Critical Introduction, London: Routledge.

Dryzek, J.S. and Niemeyer, S. (2010). Foundations and Frontiers of Deliberative Governance, Oxford: Oxford University Press.

Forester, J. (2009). Dealing with Differences: Dramas of Mediating Public Disputes, Oxford: Oxford University Press.

Gutmann, A. and Thompson, D. (2004). Why Deliberative Democracy? Princeton, NJ: Princeton University Press.

Habermas, J. (1996). Between Facts and Norms: Contributions to a Discourse Theory of Law and Democracy, Cambridge, MA: MIT Press.

Hanssen, G.S. and Saglie, I.-L. (2010). Cognitive closure in urban planning, Planning Theory and Practice, 11(4), 499-521, DOI: 10.1080/14649357.2010.525373.

Healey, P. (1993). Planning through debate: The communicative turn in planning theory. In Fischer, F. and Forester, J. (Eds), The Argumentative Turn in Policy Analysis and Planning, London: Duke University Press Books, pp. 233-253.

Held, D. (2006). Models of Democracy, Cambridge, UK: Polity.

Hillier, J. (2002). Shadows of Power: An Allegory of Prudence in Land-Use Planning, London: Routledge.

Hillier, J. (2003). Commentary: Puppets of populism? International Planning Studies, 8(2), 157166, DOI: $10.1080 / 13563470305155$.

Innes, J.E. and Booher, D.E. (1999). Consensus building as role playing and bricolage, Journal of the American Planning Association, 65 (1), 9-26.

Jones, M. and Stenseke, M. (Eds) (2011). The European Landscape Convention: Challenges of Participation, New York: Springer.

Mouffe, C. (2000). The Democratic Paradox, New York: Verso.

Mouffe, C. (2005a). On the Political, Abingdon, UK: Routledge.

Mouffe, C. (2005b). The Return of the Political, London: Verso.

Nordahl, B. (2006). Deciding on Development: Collaboration between Markets and Local Governments, Doctoral thesis no 96, Trondheim: Norwegian University of Science and Technology, Faculty of Architecture and Fine Art, Department of Urban Design and Planning.

Pateman, C. (1970). Participation and Democratic Theory, Cambridge, UK: Cambridge University Press.

Pateman, C. (1989). The Disorder of Women: Democracy, Feminism, and Political Theory, Redwood City, CA: Stanford University Press.

Pennington, M. (2002). A Hayekian liberal critique of collaborative planning. In Allmendinger, P. and Tewdwr-Jones, M. (Eds), Planning Futures: New Directions for Planning Theory, London and New York: Routledge, pp. 187-205.

Pløger, J. (2004). Strife: Urban planning and agonism, Planning Theory, 3(1), 71-92, DOI: $10.1177 / 1473095204042318$.

Purcell, M. (2008). Recapturing Democracy: Neoliberalization and the Struggle for Alternative Urban Futures, Hoboken, NJ: Taylor and Francis.

Purcell, M. (2009). Resisting neoliberalization: Communicative planning or counter-hegemonic movements? Planning Theory, 8(2), 140-165, DOI: 10.1177/1473095209102232.

Rydin, Y. (2007). Re-examining the role of knowledge within planning theory, Planning Theory, 6(1), 52-68, DOI: 10.1177/1473095207075161.

Sager, T. (2013). Reviving Critical Planning Theory: Dealing with Pressure, Neo-Liberalism, and Responsibility in Communicative Planning, London: Routledge.

Schumpeter, J.A. (1942). Capitalism, Socialism, and Democracy, New York: Harper.

Scott, J. and Marshall, G. (2009). A Dictionary of Sociology, Oxford: Oxford University Press. 
Strand, A. and Næss, P. (2017). Local self-determination, process-focus and subordination of environmental concerns, Journal of Environmental Policy and Planning, 19(2), 1-12, DOI: 10.1080/1523908X.2016.1175927.

Vick, J. (2015). Participatory versus radical democracy in the 21st century: Carole Pateman, Jacques Rancière, and Sheldon Wolin, New Political Science, 37(2), 204-223, DOI: 10.1080/07393148.2015.1022960.

Young, I.M. (2000). Inclusion and Democracy, Oxford: Oxford University Press.

Young, I.M. (2001). Activist challenges to deliberative democracy, Political Theory, 29(5), $670-690$. 